\title{
10. From philanthropy to social entrepreneurship
}

\author{
Shurlee Swain ${ }^{1}$
}

If leadership, as Amanda Sinclair argues in this volume, is to be defined in terms of the ability to influence and change the public agenda and improve the life experiences of people both in the present and in the future then philanthropy provides an excellent field in which to explore its application to women. Philanthropy, in its nineteenth-century usage, encompassed both the giving of money and the giving of time in the service of others. While women seldom commanded large fortunes, they were able to give of their time both to the administration of charitable institutions and to the provision of direct services. Philanthropy was a responsibility and an assertion of class and provided an avenue through which women could develop and display their leadership abilities. This chapter studies the ways in which women's philanthropy was transformed during the twentieth century. It argues that rising levels of education opened professional careers to women who traditionally would have been involved in philanthropy, not least the new profession of social work, which took control of many of the spheres previously the domain of charity. These same forces, however, also increased the number of women in control of substantial fortunes, and these women, influenced by second-wave feminism, were leaders in shaping new forms of philanthropy that seek to move beyond amelioration and to promote social change.

\section{Nineteenth-century philanthropy}

'Denied access to political participation and barred from remunerative occupations', Kathleen McCarthy has argued, 'middle-class women donors, volunteers and organisational entrepreneurs ... [used] philanthropic contributions of time, money and possessions ... to carve out a public niche for themselves'. ${ }^{2}$ When, in 1905, a Melbourne newspaper acclaimed the city's 10 leading citizens, the only two women who made the list were there by virtue of their philanthropy. ${ }^{3}$ In the 15 months from August 1909 to November 1910,

\footnotetext{
1 Australian Catholic University.

2 Kathleen McCarthy, 'Women and Philanthropy', Voluntas: International Journal of Voluntary and NonProfit Organisations 7(4) (1996): 332.

3 The two women named were Janet, Lady Clarke, and Selina Sutherland. Herald, 31 May 1905, cited in Annette Lewis, 'Janet Lady Clarke (1851-1909). Leader in the Good Work', PhD thesis, Deakin University, Melbourne, 2010, 26.
} 
Australia lost both of these women, plus three others who had been stalwarts of nineteenth-century philanthropy. Their lives epitomised McCarthy's argument for the efficacy of philanthropy as an avenue to power at a time when woman's place was traditionally constrained within the bounds of family and home. Yet the diversity of their experiences also illustrates that the philanthropic pathway was a varied one, suggesting, at the beginning of the twentieth century, the multiple ways in which 'doing good' would provide opportunities for leadership for women over the coming decades.

The lives of Elizabeth Austin and Janet, Lady Clarke, modelled an older notion of philanthropy, a form of noblesse oblige that tarnished the term until quite late in the new century. Proclaimed on her death in November 1910 as 'a thoroughly good philanthropic woman', ${ }^{4}$ Austin was the widow of a wealthy pastoralist. Although she had engaged in the charitable activities expected of a woman of her class throughout her marriage, in her widowhood she moved to philanthropy on a larger scale, initially anonymously, using a son-in-law to speak on her behalf, but later more openly, always taking an interest in the management of the institutions she had funded. ${ }^{5}$ As the wife of Victoria's richest man, and Australia's only hereditary baronet, Janet, Lady Clarke, enthusiastically embraced the philanthropic responsibilities that came with her position. Carefully schooled in her new role by Lady Bowen, the wife of the Victorian governor, she accepted invitations to join the committees of most Melbourne charities concerned with the welfare of women and children, although as a young mother with a growing family, and later a society hostess with a range of other responsibilities, she was not always assiduous in her attendance. When Clarke died in November 1909, The Argus declared '[a]ny movement that had for its aim the welfare of the community, in the uplifting of humanity, found in her a ready, willing, and able ally'. ${ }^{6}$ Many of the recipients of her beneficence lined the streets for her funeral procession-one of the most impressive Melbourne had seen to that time. ${ }^{7}$ Clarke's most recent biographer has defended her against accusations that her philanthropic activity was 'simply a public demonstration of the noblesse oblige idea', arguing instead that her religious faith inspired 'a genuine commitment to improve living standards for the underprivileged in society', and a desire to 'bring permanent changes' in their lives. ${ }^{8}$ Certainly, she

\footnotetext{
4 'Obituary', Kilmore Free Press [Victoria], 8 September 1910: 2, http://nla.gov.au/nla.news-article58275711.

5 Shurlee Swain, 'Perhaps to Spite Her Children: The Philanthropy of Elizabeth Austin', Australian Philanthropy (30) (1996): 10-15.

6 'Janet Lady Clarke. Her Death Announced', The Argus [Melbourne], 29 April 1909: 6, http://nla.gov.au/ nla.news-article10708702.

7 'Janet Lady Clarke. An Impressive Funeral', The Argus [Melbourne], 30 April 1909: 4, http://nla.gov.au/ nla.news-article10681512.

8 Lewis, 'Janet Lady Clarke (1851-1909)', 134.
} 
did actively involve herself in management and policy development in relation to the organisations with which she was involved; however, her philanthropy remained an interest rather than a profession.

In this sense, Catherine Helen Spence can be seen as a transitional figure. A single woman with no independent income, she earned a living through writing, building a public profile as a commentator on social issues, initially in South Australia, but later nationally. While her obituary constructed her as an observer of both the transformation of 'the objects and organization of philanthropic and charitable enterprises' and the 'official recognition of the value of women's work upon various Government boards', this disguises the degree to which she was a participant in these interlinked processes. ${ }^{9}$ Spence understood herself as 'a new woman ... awakened to a sense of capacity and responsibility, not merely to the family and the household, but to the State'. ${ }^{10}$ Although she never took a salary from her work for state children, the prominent role she played laid firm foundations for the women who would make such work a profession in the years following her death. ${ }^{11}$ Mary MacKillop (St Mary of the Cross), who died in August 1909, and Selina Sutherland, who died in October 1909, had no independent financial resources and hence were supported through their philanthropic activities, MacKillop through the religious order which she co-founded, and Sutherland through honoraria donated by the supporters of the four separate child-rescue organisations she established during her lifetime. While MacKillop's death passed with little notice in the secular press, ${ }^{12}$ Sutherland was acclaimed as a 'great philanthropist', ${ }^{13}$ 'a fine figure in the records of Victorian charity, a hard worker, and a woman whose heart was in her work'. ${ }^{14}$ In the twentieth century, the path tentatively pioneered by Sutherland and MacKillop would provide professional leadership opportunities to large numbers of women, although the older model of voluntary charity did not entirely disappear.

The women who carried nineteenth-century notions of philanthropy into the twentieth rarely spoke about their motivation. Nor would they have called themselves leaders. Confined within conventional feminine tropes of silence, secrecy and sacrifice, they did not talk publicly about the positions they occupied, leaving it to others to praise them, usually after their deaths, in

\footnotetext{
9 'Honouring a Grand Old Woman', The Register [Adelaide], 31 October 1910: 6, http://nla.gov.au/nla.newsarticle59129722.

10 'Miss Spence, Octogenarian', The Register [Adelaide], 31 October 1905: 6, http://nla.gov.au/nla.newspage4423118.

11 Catherine Spence, State Children in Australia (Adelaide: Vardon \& Sons, 1907).

12 'Personal', The Advertiser [Adelaide], 10 August 1909: 6, http://nla.gov.au/nla.news-article5753659.

13 'The Death of Miss Sutherland, the Great Philanthropist', Fitzroy City Press [Melbourne], 15 October 1909: 3, http://nla.gov.au/nla.news-article65684211.

14 'Death of Miss Sutherland', The Argus [Melbourne], 9 October 1909: 19, http://nla.gov.au/nla.newsarticle10739458.
} 
ways that sought more to present them as exemplars of the feminine rather than as individuals who were challenging perceptions of women's place. Angela Woollacott has identified World War I as a key point of transition in women's activity in the public sphere. ${ }^{15}$ Australia provides an interesting arena in which to study this shift. Its early enfranchisement of women provided alternatives to philanthropy as a way of bringing about change, with activists on both the left and the right now able to exercise power through feminist, industrial or political organisations. ${ }^{16}$ First-wave feminism had opened higher education to women, with graduates increasingly able to base their claims to leadership on professional competence rather than moral authority. While several of the prominent early graduates struggled to gain acceptance in their professions, they were able to use their qualifications to take a leadership role in the philanthropic sphere, recasting the work as an obligation that came from their higher education. ${ }^{17}$ Compelled by ill health to withdraw from her distinguished academic career, Melbourne scientist Dr Georgina Sweet transferred her talents to the community sphere, rising to international leadership in two organisations promoting the welfare of women. As a single woman, and the sole survivor of her family, she was also a substantial philanthropist both during her life and after her death, focusing her giving on increasing the educational opportunities for women. Another early science graduate, Ada à Beckett, was able to draw on the resources of her barrister husband as well as her own talents to combine paid employment and family life while still pursuing the philanthropic activities expected of a woman of her class, always grounding her decisions in research rather than the moral judgments that had dominated the field in the past. ${ }^{18}$

The gradual construction of a welfare state rendered marginal many activities previously conducted by women; however, a space remained both for women who found themselves in command of a large fortune to make substantial donations to philanthropic causes and for other, often less affluent women to build a career out of what would previously have been seen as purely philanthropic activity. Eliza Hall had been a regular donor throughout her marriage, particularly to charities working with women and children, but it was as a widow that she made her greatest contribution. Childless and the major beneficiary of her mining magnate husband's estate, she established a trust to make regular distributions to religious, financial and educational causes across

15 Angela Woollacott, 'From Moral to Professional Authority: Secularism, Social Work and Middle-Class Women's Self Construction in WW1 Britain', Journal of Women's History 10(2) (1998): 85.

16 Shurlee Swain, 'Women and Philanthropy in Colonial and Post-Colonial Australia', Voluntas: International Journal of Voluntary and Non-Profit Organisations 7(4) (1996): 440.

17 'Women and Universities', The Register [Adelaide], 8 June 1925: 5, http://nla.gov.au/nla.newsarticle54915469.

18 Julie Marginson, 'à Beckett, Ada Mary (1872-1948)', Australian Dictionary of Biography Online (Canberra: National Centre of Biography, The Australian National University), http://adb.anu.edu.au/biography/abeckett-ada-mary-4963/text8235. 
the three States in which the fortune had been amassed. ${ }^{19}$ Victorian stud breeder Janet Biddlecombe was also a childless widow whose philanthropy was largely hidden until after her death; however, she differed from Hall in that the money she donated was substantially her own, the result of her success in reviving the pastoral holding she controlled after the death of her father. ${ }^{20}$ For each of these women, philanthropy bought immortality, Hall's name incorporated into the Walter and Eliza Hall Institute funded from the trust and Biddlecombe's in properties constructed as a result of her donations and bequests.

Melbourne's Edith Onians, described as 'mother to the newsboys', was independently wealthy so did not need to seek paid employment, but she built a career nevertheless, using her position as honorary secretary to the City Newsboys Society as a base from which to build a reputation as an expert in the field of boy rescue, travelling, speaking and writing and, eventually, being appointed to positions on government and non-governmental organisations. ${ }^{21}$ In Adelaide, Annie Green, who commenced her career as a volunteer at the City Mission, rose to become its first female superintendent. In the process, the role of the superintendent was reconceptualised from one of managing to one of caring, and hence one appropriately undertaken by a woman, although the essential tasks remained unchanged. ${ }^{22}$ Anglican sister Kate Clutterbuck established two of Perth's major children's homes, taking the title first of 'Mum', and later of 'Gran', to the hundreds of children who passed through her care. ${ }^{23}$ The use of maternal terms to describe such women is also indicative of the pathway philanthropy offered towards social motherhood - a status that positioned them as superior to the biological mothers of the children they set out to help. Such a positioning had the potential to disempower poor mothers under the guise of assisting their children.

While the organisations that emerged as a medium for women's activism - the National Council of Women, Red Cross, the Country Women's Association and the Young Women's Christian Association-continued to use the language of

19 Hazel King, 'Hall, Eliza Rowdon (1847-1916)', Australian Dictionary of Biography Online (Canberra: National Centre of Biography, The Australian National University), http://adb.anu.edu.au/biography/halleliza-rowdon-7056/text11215.

20 Diane Langmore, 'Biddlecombe, Janet (1866-1954)', Australian Dictionary of Biography Online (Canberra: National Centre of Biography, The Australian National University), http://adb.anu.edu.au/biography/ biddlecombe-janet-107/text16729.

21 'Miss Edith Onians was “Mother" to the Newsboys', The Age, 18 August 1955: 2, http://news.google.com/ newspapers? nid $=1300 \&$ dat $=19550818 \& \mathrm{id}=$ cYYQAAAAIBAJ $\&$ sjid $=5 Z$ ZDAAAAIBAJ \&pg $=7194,2634283$.

22 'The Submerged Tenth', The Mail [Adelaide], 17 February 1923: 18, http://nla.gov.au/nla.newsarticle63779161; Julie-Ann Ellis, 'Green, Anne Syrett (1858-1936)', Australian Dictionary of Biography Online (Canberra: National Centre of Biography, The Australian National University), http://adb.anu.edu.au/ biography/green-anne-syrett-12950/text23405.

23 Noël Stewart, 'Clutterbuck, Katherine Mary (1861-1946)', Australian Dictionary of Biography Online (Canberra: National Centre of Biography, The Australian National University), http://adb.anu.edu.au/ biography/clutterbuck-katherine-mary-5691/text9619. 
maternalism, they provided valuable avenues through which women could develop and demonstrate a range of non-maternal leadership skills on the local, national or international stage. The positions on which they chose to take a stand, however, all too often made them appear backward and judgmental compared with the progressive, benevolent, supposedly universalist state - a view that was reinforced by the fact that "philanthropists were generally in the vanguard of opposition to social change' ${ }^{24}$ Tasmania's Emily Dobson (18421934) was described as being involved in every charitable organisation in the State. The wife of the premier, and associated in her own right with a range of conservative political organisations, she argued that her aim was to 'improve all sections of society'. Like most elite philanthropic women, however, she saw that change as taking place 'within the context of existing society' ${ }^{25}$ Zina CumbraeStewart dominated Brisbane's charitable network in a similar way, arguing vigorously for suitably qualified women to be given greater responsibility in public life, while urging other women to resist modernity and to support rather than compete with men. When, during World War I, the Government moved to regulate working conditions for domestic servants, she was strident in her opposition, arguing that 'if servants were given more leisure their mistresses would have less time to devote to charitable works' ${ }^{26}$

On the committees that still controlled such major charities as hospitals, and agedcare and children's homes, women fought for acceptance where membership had previously been restricted to men, and in turn invited prominent men to join their own organisations, but in both cases, the result, too often, was a confining of women to the more 'domestic' roles, defining leadership in terms of skills more commonly coded male. ${ }^{27}$ The result, social work historian R. J. Lawrence concluded, was a 'cleavage' in the administration of welfare:

On the one hand there was an approach through broad legislative measures, sponsored by political parties and administered by government, largely male, officials; on the other was an approach through numerous small voluntary organizations, catering for individual needs, sponsored by a wide variety of citizen groups or churches, with detailed work largely in the hands of unpaid women in the higher income groups. ${ }^{28}$

24 Swain, 'Women and Philanthropy in Colonial and Post-Colonial Australia', 437.

25 Alison Alexander, 'Perceptions of Women's Role in Tasmania, 1803-1914', Bulletin of the Centre for Tasmanian Historical Studies 3(2) (1991-92): 96.

26 Jean Stewart, 'Zina Beatrice Selwyn Cumbrae-Stewart: A Powerful Woman', Journal of the Royal Historical Society of Queensland 19(1) (February 2005): 610-27.

27 Swain, 'Women and Philanthropy in Colonial and Post-Colonial Australia', 440.

28 Robert Lawrence, Professional Social Work in Australia (Canberra: The Australian National University, 1965), 29. 
Even where social reform created the opportunity for paid employment in what had been the philanthropic sector, 'a woman supported by her husband, or by a private income was, from a financial viewpoint, the ideal worker for agencies short of funds' ${ }^{29}$

This is not to argue that there was no place for the older model of elite female philanthropy, nor that it did not continue to offer significant leadership opportunities to elite women. In Victoria, Dame Mabel Brookes reigned over the Queen Victoria Hospital from 1923 until five years before her death in 1975. ${ }^{30}$ As president, she waged a long battle to get adequate accommodation for the hospital - a struggle she described in feminist terms as 'a fight by women against prejudice, suspicion and intolerance of women'. When the hospital was finally relocated to the refurbished Melbourne Hospital site, she declared 'there's no finer feeling than winning the supposedly hopeless battle'. ${ }^{31}$ Her struggle was not dissimilar to that of Sydney's Dr Lucy Gullett (1876-1949), who, according to early social worker Katharine Ogilvie, 'used her wit, her gift of words, her kindness and her unreasonable optimism to touch the hearts of women in every walk of life and in every part of Sydney, so that they became permanent and ardent supporters' of the Rachel Forster Hospital, which she had founded, as, like the Queen Vic, a hospital in which women could be treated by female doctors. ${ }^{32}$ Hospital administration also provided a power base for Melbourne's Dame Elisabeth Murdoch, who, understanding philanthropy as a responsibility attached to wealth, involved herself in a wide range of causes in the early years of her marriage. Widowed in 1952, she began a pattern of substantial donations, and two years later assumed the presidency of the Royal Children's Hospital, a position she occupied for 11 years, during which she oversaw both the fundraising and the organisation involved in rebuilding the hospital on a new site. While she tolerated the socialising that committee membership involved, she came increasingly to advocate direct giving, which, she believed, 'would ease the burden of committees and leave them freer to do necessary work'. ${ }^{33}$

At the local level, philanthropy continued to provide an important way of building community, with groups of women coming together to establish many of the services that would later be taken over by the state. Women who rose to leadership in such local organisations were sent as representatives to State and national organisations such as the Country Women's Association (CWA) and

\footnotetext{
29 Ibid., 28.

30 Laurie O'Brien and Cynthia Turner, 'Hospital Almoning: Portrait of the First Decade', Australian Social Work 32(4) (1979): 9.

31 Dame Mabel Brookes (as told to Michael Courtney), 'The Hour I'll Never Forget', The Argus [Melbourne], 19 January 1956: 8, http://nla.gov.au/nla.news-article72531074.

32 'Dr Lucy Gullett', Sydney Morning Herald, 18 November 1949: 2, http://nla.gov.au/nla.newsarticle18135727.

33 'Influence of Home', The Courier-Mail [Brisbane], 5 August 1939: 1, http://nla.gov.au/nla.newsarticle40832252.
} 
the National Council of Women (NCW), providing rural and suburban women with the opportunity to influence national debates. Lottie Leal, for example, rose from her base in suburban Thebarton, to lead the SA NCW. She did not embrace feminism, arguing that women 'should command respect not demand it', earning positions of authority through their intelligence rather than being 'thrust forward ... merely to give them equality with men', ${ }^{34}$ but she served as an influential role model to younger women, representing women's interests on several State committees. Launceston widow Nellie Dougharty found in philanthropy an occupation to fill the gap in her life after her young husband died during World War I. Although she had few financial resources to donate to her many causes, she developed talents as an organiser and advocate, which saw her recognised as a leader in her local community. ${ }^{35}$

\section{The advent of professional social work}

The shift Woollacott has identified was more apparent in the development of the profession of social work in Australia; however, it would be incorrect to position this in opposition to established models of philanthropy. The call for the introduction of professional social work was championed by female philanthropists through conservative women's organisations, and the first women who entered the profession often came from families with long traditions of philanthropic engagement. Brookes, initially, had been sceptical of the need for the new profession, but after visiting several hospitals in England her scepticism changed to enthusiasm. On her return, she convened a meeting to gain support for a local Institute of Almoners. ${ }^{36}$ Mrs Kent Hughes, a member of the Melbourne Hospital auxiliary, having seen British almoners at work during a similar trip, persuaded her fellow auxiliary members to raise the money that brought Agnes Macintyre to Melbourne in 1929 to establish the first almoners' training program. ${ }^{37}$ Almoners' departments were established in Victorian public hospitals over the next decade but the expectation was that they would continue to be funded by women's voluntary fundraising. In Sydney, the path to professionalisation was forged by an alliance of three women's groups - the NCW, the Young Women's Christian Association (YWCA) and women involved in industrial welfare - who together established the Board of Social Studies and Training in $1928 .^{38}$ In order to realise their ambition of having professional

\footnotetext{
34 'National Council News', The Advertiser [Adelaide], 17 September 1930: 6, http://nla.gov.au/nla.newsarticle73824206.

35 Jeanette Roelvink, 'Dougharty, Helen Elizabeth (Nellie) (1886-1968)', Australian Dictionary of Biography Online (Canberra: National Centre of Biography, The Australian National University), http://adb.anu.edu.au/ biography/dougharty-helen-elizabeth-nellie-12891/text23289.

36 Lawrence, Professional Social Work in Australia, 34.

37 Ibid., 35

38 Damian J. Gleeson, 'Some New Perspectives on Early Australian Social Work', Australian Social Work 
training move from the philanthropic to the university sector, women in both cities were forced to forge alliances with sympathetic men within the academy. This began a pattern in which the leadership opportunities for women inherent in a profession that was and has continued to be female dominated were often seen as a threat to its status. ${ }^{39}$

The early years of professional social work in Australia reflect the cleavage Lawrence has identified in social welfare more generally. The graduates of the new training courses, joined by women who had undertaken courses in the United States, were engaged in a process of defining the new profession; however, opportunities to exercise leadership were constrained both by gender and by their status as employees. ${ }^{40}$ The widespread restrictions on the employment of married women meant that only the minority who remained single stayed long enough in the profession to gain substantial expertise, leaving the even smaller group of male graduates with privileged access to senior positions. ${ }^{41}$ The first graduates were concentrated in hospitals where they were commonly positioned alongside nurses as providing a service to the male-dominated medical profession. ${ }^{42}$ When professional education moved into the universities, male academics delivered the theoretical content, leaving women, working under male direction, to deal with the practical aspects. ${ }^{43}$ Although for most of the male academics teaching into the social work course was a sideline to their main responsibilities, women were not seen as eligible to take positions of leadership. ${ }^{44}$ Appointed to the University of Sydney in 1945, Norma Parker acted as program director repeatedly over the next 14 years, as male directors came and went, but was never offered the position on a permanent basis. ${ }^{45}$ Lawrence, who was later to become Australia's first professor of social work, found this apparent oversight unsurprising. Parker's interest, he claims, 'was not in administration; she was primarily a first-rate practitioner and teacher of social casework' - a claim that seems to ignore her leadership roles outside the academy, as founding president of the Australian Association of Social Workers, a position she held from 1946 to 1953, and the key role she played in the foundation of the Australian Council of Social Services. ${ }^{46}$ Parker's experiences were far from unusual. Amy Wheaton, director of the Adelaide course, did

\footnotetext{
in New South Wales', Australian Social Work 38(1) (1985): 35.

39 Marchant, 'A Feminist Perspective on the Development of the Social Work Profession in New South Wales', 39.

40 Lawrence, Professional Social Work in Australia, ix.

41 Elaine Martin, 'Themes in a History of the Social Work Profession', International Social Work 35 (1992):

333.

42 Ibid., 338.

43 Marchant, 'A Feminist Perspective on the Development of the Social Work Profession in New South Wales', 40; Frances Crawford and Sabina Leitmann, 'The Midwifery of Power? Reflections on the Development of Professional Social Work in Western Australia', Australian Social Work 54(3) (2001): 47.

44 Lawrence, Professional Social Work in Australia, 44.

45 Ibid., 130.

46 Ibid.
} 
most of the teaching, but only after her health broke down was she offered an increase in staff and a 'belated rise in her status' ${ }^{47}$ Appointed to the University of Queensland in 1973, Edna Chamberlain was Australia's first female professor of social work, ${ }^{48}$ but well into the 1970s the heads of Australian schools of social work continued to be male, often from overseas, and rarely with substantial practical experience. ${ }^{49}$

Outside the academy the early social workers had to tread a cautious path in order to advance the claims of the new profession without alienating either the philanthropic women who until then had commanded the field or the male professionals and managers on whose support they were dependent. ${ }^{50}$ Accounts of the way in which they negotiated this task tend to emphasise qualities coded as female. Sydney social worker Kate Ogilvie, for example, is applauded as a 'forceful leader' and a formidable advocate for her cause, yet her success is ascribed to her 'personal gifts ... and her capacity for relationships and for inspiring confidence'. ${ }^{51}$ Norma Parker was described as 'not ambitious', but rather 'she did things because they needed to be done', creating opportunities for 'good people' rather than claiming the credit for herself. ${ }^{52}$ In her reminiscences, Parker noted how, during her early days in Melbourne, she came to realise that 'one served quite a long apprenticeship before you earned the right to have anything to say ... It took years to be accepted; when that happy day finally arrived, all was well, but it was a weary process'.$^{53}$

\section{A gendered profession}

Although World War II created greater opportunities for female social workers to exercise leadership, particularly through the expansion of the Red Cross, ${ }^{54}$ the gender imbalance continued to be seen as a problem for the status of the profession well into the 1960s. Lawrence's 1965 history of social work returns to this theme repeatedly when looking towards the future. The women attracted to the work, he argues, were all too easily dismissed as 'nice girls from nice families', while the single women who 'provided the group's work with continuity and leadership ... were "career women" ... sometimes unkindly described as

\footnotetext{
47 Ibid., 53.

48 Stephanie Green, 'Edna Chamberlain: In Retrospect', Australian Social Work 47(3) (1994): 7.

49 Crawford and Leitmann, 'The Midwifery of Power?', 47.

50 S. Greig Smith, 'Three Ladies from England', Forum 7(2) (1954): 1-2; O'Brien and Turner, 'Hospital Almoning', 11.

51 Smith, 'Three Ladies from England', 1-2; Norma Parker, 'Katharine Ogilvie', Australian Social Work 36(2) (1983): 4.

52 Millie Mills, 'Editorial', Australian Social Work 39(2) (1986): 3.

53 Norma Parker, 'Early Social Work in Retrospect', Australian Social Work 32(4) (1979): 19.

54 Lawrence, Professional Social Work in Australia, 90.
} 
"frustrated spinsters"". ${ }^{55}$ The future of the profession, Lawrence believed, lay in attracting more men, who would display a greater sense of commitment in the early stages of their career, stay longer in the profession and, rather than accept inadequate employment conditions, would insist on independent and equal status with the older established professions. Men, he argued, could move smoothly into positions of leadership. Unhampered by community attitudes to professional women, they could more easily bridge the gaps between government and non-governmental agencies. Equal in importance, however, was his assumption, grounded in contemporary gendered understandings of leadership, that men were implicitly more rounded individuals who relied 'less completely upon their work for social and personal satisfactions because they have a family and home of their own', took a broader view of individual problems and were generally more aware of the 'father's part in life'.$^{56}$

The relaxation of restrictions on married women's employment saw more women remaining or returning to the profession by the 1970s; however, the increase in numbers was not immediately reflected in a rise in the proportion of leadership positions occupied by women. A developing feminist analysis highlighted the 'fundamentally patriarchal assumptions' that functioned to advantage men. ${ }^{57}$ Some of these advantages were structural. While ameliorative provisions such as child care and part-time work had been introduced to overcome labour shortages, the underlying assumption remained that mothers were the ones who were responsible for managing the family. The career of the male social worker could proceed unimpeded because he had a wife at home to deal with these responsibilities. ${ }^{58}$

A more significant barrier to progression, however, was identified in the definitions of leadership that operated in the field-definitions that favoured indirect policy or administrative roles over female-dominated casework. ${ }^{59}$ This division now came to be understood as indicative of patriarchal oppression, internalised by male and female social workers alike. Caring work was coded female, transferring into the workplace the responsibilities assumed by women in the home. Female social workers were constituted as 'the housewives of society', while leadership status was conferred on those who occupied nondirect practice positions, still effectively coded male. ${ }^{60}$ Although the last decades of the twentieth century saw many more women move into positions of

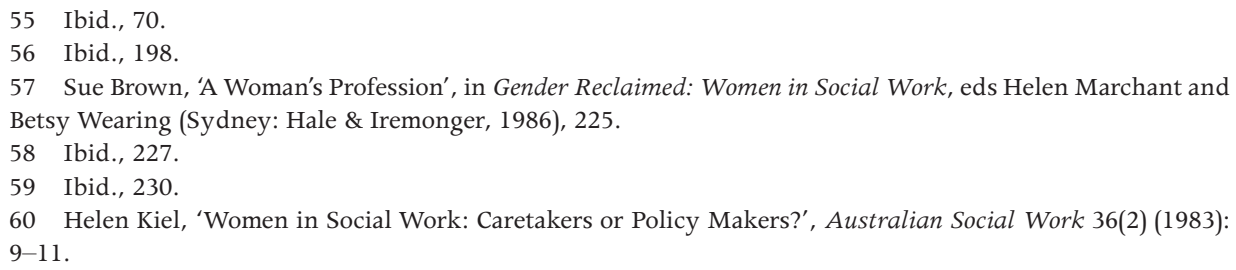


leadership, they generally did so only by accepting masculinised definitions of what leadership in the profession actually entailed, rather than by challenging the gendered devaluation of care.

\section{Feminist philanthropy}

While the profession struggled with such issues, women's philanthropy was being transformed. By the end of the century, women in employment were more likely to give than their male counterparts, and they gave a larger proportion of their taxable income. ${ }^{61}$ The desire to make a difference is undoubtedly an important motivation, but philanthropy continues to provide opportunities for female empowerment, establishing and managing their own foundations rather than being subsumed within existing male-dominated structures. ${ }^{62}$ Although remnants of the society fundraiser continue, ${ }^{63}$ the term philanthropy is increasingly associated with notions of social enterprise or social entrepreneurship, as a new generation of women, influenced by 1970s feminism, seeks to use their inherited or earned wealth for change rather than relief. ${ }^{64}$ The focus for this new philanthropy is Melbourne, but it has attracted supporters in other States, coming together as the Women Donors Network, which aims to direct its members to use their donations to address the 'unique circumstances and specific needs of women and girls' ${ }^{65}$

In her later years, Dame Elisabeth Murdoch was a precursor and a role model for this new generation of philanthropists. While many of her early donations had been anonymous, she came to believe that being publicly identified as a leader was important, not for her personal glory but in the hope that her example would encourage other people. She also argued that philanthropists needed to be actively involved in the work they were assisting. 'The advantage of wealth is that you have an opportunity to do so much good ... it's perfectly easy to give it away and nothing to be particularly proud of but it's being involved and knowing what you are helping' that are important. ${ }^{66}$ Murdoch chose the causes she would support, and while her donations to key cultural and charitable

61 Margaret Steinberg and Lara Cain, Putting Paid to Prescribed Roles: A New Era for Australian Women and Philanthropy, Working Paper No. CPNS16 (Centre of Philanthropy and Nonprofit Studies, Queensland University of Technology, Brisbane, 2003), 8.

62 Ibid.

63 See, for example, the story of Sydney's Lady Mary Fairfax in Michael Gilding, Secrets of the Super Rich (Sydney: HarperCollins, 2010), ch. 7.

64 Anne O'Brien, 'Charity and Philanthropy', Dictionary of Sydney, http://www.dictionaryofsydney.org/ item $/ 251$.

65 'Women Donors Investing in Women and Girls', http://www.womendonors.org.au/index. php?option $=$ com_content $\&$ view $=$ article \&id $=38 \&$ Itemid $=95$.

66 Transcript, Enough Rope, ABC TV, 23 June 2008, http://www.abc.net.au/tv/enoughrope/transcripts/ s2283021.htm. 
organisations were substantial, she also supported a drama group for women prisoners and work amongst newly arrived refugees, causes that took her well outside her conservative social circle. ${ }^{67}$

A key leader amongst the new generation of philanthropists is Jill Reichstein, who, radicalised in the protests of the 1960s, was quickly frustrated with the conservative, ameliorative approach taken by her father's foundation, which she joined at the age of twenty-six. Assuming the chair 10 years later, she transformed its approach, influenced by the concept of social change philanthropy. ${ }^{68}$ In America, she argues, 'when you have excess wealth it's your responsibility to share it', and social change philanthropy enables her to blend this philosophy with her feminist principles. Her notion of leadership attempts to break down the hierarchy between the 'donor and the donee' through working in partnership with the groups which are funded in order to bring about change. ${ }^{69}$ Reichstein believes women's work experience equips them to provide a very different type of philanthropic leadership. Where the men who run foundations traditionally have come from a banking or finance background, the women who move into the sector often bring experience in communitybased organisations - a move she describes as shifting roles 'from poacher to gamekeeper' ${ }^{70}$

Women at the forefront of this movement only accept the label of leader if they are able to redefine it in feminist terms. As long as leadership is seen to be acting with passion, or mentoring and helping to effect change through education, then I am comfortable with being called a leader', says Reichstein. ${ }^{71}$ Businesswoman Carol Schwartz sees her philanthropy as part of her commitment to negotiating 'the complicated relationship between making money and creating social good' ${ }^{72}$ For Eve Mahlab, co-founder of the Australian Women Donors Network, social change philanthropy represents the third wave of the women's movement: 'The first got us the vote. The second gave us more access to decently paid work rather than the unpaid home duties in which we had previously been trapped. We must now move into policy and decision making roles at all levels.' The challenge for women who have benefited from the first two waves of the movement is to use their advantage for the benefit of other women and their

67 Elizabeth Cham, 'Foreword', Australian Philanthropy: Honouring the Philanthropy of Dame Elisabeth Murdoch 51 (2003): 2, http://www.philanthropy.org.au/pdfs/philaus/AustralianPhilanthropy_Issue51.pdf.

68 Briony Goode, 'Change for the Better', WellBeing [Mosman, NSW] 126 (2010): 27.

69 'Women of Power and Influence', Compass, ABC TV, 25 February 2007, http://www.abc.net.au/compass/ s1835941.htm.

70 Jill Reichstein, 'On Women and Philanthropy', Australian Philanthropy 71 (2008): 12.

71 Jill Reichstein, Interviewed by Nikki Henningham for the Women and Leadership in a Century of Australian Democracy Oral History Project, in Melbourne, 12 May 2011, National Library of Australia, Canberra, http://nla.gov.au/nla.cat-vn5216522.

72 Carol Schwartz, Interviewed by Nikki Henningham for the Women and Leadership in a Century of Australian Democracy Oral History Project, in Melbourne, 11 May, 22 June and 13 September 2011, National Library of Australia, Canberra, http://nla.gov.au/nla.oh-vn5216518. 
families, practising a new type of leadership that involves working alongside rather than for the people they identify as being in need. ${ }^{73}$ Mahlab's call has found a receptive audience amongst young successful women determined to use at least some of their private wealth and their professional skills for public rather than personal benefit. ${ }^{74}$

\section{Conclusion}

At the end of the twentieth century the bulk of caring work continued to be coded female. With the welfare state in retreat, governments again sought to encourage philanthropy. Advances in women's education had, however, diversified the leadership opportunities that such activity offered, with women increasingly earning and controlling assets in their own right. While it would be unrealistic to overestimate the influence of social change philanthropy on the field as a whole, it does provide evidence that while social workers remain ambivalent about confronting gendered notions of leadership, women in philanthropy have moved from a situation where they used philanthropy as an avenue to leadership and power, to one in which they employ their leadership skills and power in the interests of philanthropy.

\section{References}

Alexander, Alison. 'Perceptions of Women's Role in Tasmania, 1803-1914.' Bulletin of the Centre for Tasmanian Historical Studies 3(2) (1991-92): 81-98.

Brookes, Dame Mabel (as told to Michael Courtney). 'The Hour I'll Never Forget.' The Argus [Melbourne], 19 January 1956: 8. http://nla.gov.au/nla. news-article72531074.

Brown, Sue. 'A Woman's Profession.' In Gender Reclaimed: Women in Social Work, edited by Helen Marchant and Betsy Wearing, 223-33. Sydney: Hale \& Iremonger, 1986.

Cham, Elizabeth. 'Foreword.' Australian Philanthropy: Honouring the Philanthropy of Dame Elisabeth Murdoch 51 (2003): 2. http://www.philanthropy.org.au/ pdfs/philaus/AustralianPhilanthropy_Issue51.pdf.

73 Eve Mahlab, 'Does Gender Still Matter?', Australian Philanthropy 71 (2008): 3.

74 See, for example, Kristi Mansfield, founder of the Greenstone Group - Philanthropy Advisers: http:// greenstonegroup.wordpress.com/biography/. 
Crawford, Frances and Sabina Leitmann. 'The Midwifery of Power? Reflections on the Development of Professional Social Work in Western Australia.' Australian Social Work 54(3) (2001): 43-54.

'Death of Miss Sutherland.' The Argus [Melbourne], 9 October 1909: 19. http:// nla.gov.au/nla.news-article10739458.

'Dr Lucy Gullett.' Sydney Morning Herald, 18 November 1949: 2. http://nla.gov. au/nla.news-article18135727.

Ellis, Julie-Ann. 'Green, Anne Syrett (1858-1936).' Australian Dictionary of Biography Online. Canberra: National Centre of Biography, The Australian National University. http://adb.anu.edu.au/biography/green-annesyrett-12950/text23405.

Gilding, Michael. Secrets of the Super Rich. Sydney: HarperCollins, 2010.

Gleeson, Damian J. 'Some New Perspectives on Early Australian Social Work.' Australian Social Work 61(3) (2008): 207-25.

Goode, Briony. 'Change for the Better [Jill Reichstein and the social change philanthropy movement].' WellBeing [Mosman, NSW] 126 (2010): 26-8.

Green, Stephanie. 'Edna Chamberlain: In Retrospect.' Australian Social Work 47(3) (1994): 3-11.

'Honouring a Grand Old Woman.' The Register [Adelaide], 31 October 1910: 6. http://nla.gov.au/nla.news-article59129722.

'Influence of Home.' The Courier-Mail [Brisbane], 5 August 1939: 1. http://nla. gov.au/nla.news-article40832252.

'Janet Lady Clarke. Her Death Announced.' The Argus [Melbourne], 29 April 1909: 6. http://nla.gov.au/nla.news-article10708702.

'Janet Lady Clarke. An Impressive Funeral.' The Argus [Melbourne], 30 April 1909: 4. http://nla.gov.au/nla.news-article10681512.

Kiel, Helen. 'Women in Social Work: Caretakers or Policy Makers?' Australian Social Work 36(2) (1983): 9-11.

King, Hazel. 'Hall, Eliza Rowdon (1847-1916).' Australian Dictionary of Biography Online. Canberra: National Centre of Biography, The Australian National University. http://adb.anu.edu.au/biography/hall-eliza-rowdon-7056/text11215. 
Langmore, Diane. 'Biddlecombe, Janet (1866-1954).' Australian Dictionary of Biography Online. Canberra: National Centre of Biography, The Australian National University. http://adb.anu.edu.au/biography/biddlecombejanet-107/text16729.

Lawrence, Robert. Professional Social Work in Australia. Canberra: The Australian National University, 1965.

Lewis, Annette. 'Janet Lady Clarke (1851-1909). Leader in the Good Work.' PhD thesis, Deakin University, Melbourne, 2010.

McCarthy, Kathleen. 'Women and Philanthropy.' Voluntas: International Journal of Voluntary and Non-Profit Organisations 7(4) (1996): 331-5.

Mahlab, Eve. 'Does Gender Still Matter?' Australian Philanthropy 71 (2008): 3.

Marchant, Helen. 'A Feminist Perspective on the Development of the Social Work Profession in New South Wales.' Australian Social Work 38(1) (1985): 35-43.

Marginson, Julie. 'à Beckett, Ada Mary (1872-1948).' Australian Dictionary of Biography Online. Canberra: National Centre of Biography, The Australian National University. http://adb.anu.edu.au/biography/a-beckett-adamary-4963/text8235.

Martin, Elaine. 'Themes in a History of the Social Work Profession.' International Social Work 35 (1992): 11-22.

Mills, Millie. 'Editorial.' Australian Social Work 39(2) (1986): 2-3.

'Miss Edith Onians was "Mother" to the Newsboys.' The Age, 18 August 1955: 2. http://news.google.com/newspapers? nid $=1300 \&$ dat $=19550818 \& \mathrm{id}=\mathrm{cYY}$ QAAAAIBAJ\&sjid=5ZQDAAAAIBAJ\&pg=7194,2634283.

'Miss Spence, Octogenarian.' The Register [Adelaide], 31 October 1905: 6. http:// nla.gov.au/nla.news-page4423118.

'National Council News.' The Advertiser [Adelaide], 17 September 1930: 6. http://nla.gov.au/nla.news-article73824206.

'Obituary.' Kilmore Free Press [Victoria], 8 September 1910: 2. http://nla.gov.au/ nla.news-article58275711.

O'Brien, Anne. 'Charity and Philanthropy.' Dictionary of Sydney. http:// dictionaryofsydney.org/entry/charity_and_philanthropy.

O'Brien, Laurie and Cynthia Turner. 'Hospital Almoning: Portrait of the First Decade.' Australian Social Work 32(4) (1979): 7-12. 
Parker, Norma. 'Early Social Work in Retrospect.' Australian Social Work 32(4) (1979): 13-20.

Parker, Norma. 'Katharine Ogilvie.' Australian Social Work 36(2) (1983): 3-8.

'Personal.' The Advertiser [Adelaide], 10 August 1909: 6. http://nla.gov.au/nla. news-article 5753659.

Reichstein, Jill. 'On Women and Philanthropy.' Australian Philanthropy 71 (2008): 71 .

Reichstein, Jill. Interviewed by Nikki Henningham for the Women and Leadership in a Century of Australian Democracy Oral History Project, in Melbourne, 12 May 2011. National Library of Australia, Canberra. http:// nla.gov.au/nla.cat-vn5216522.

Roelvink, Jeanette. 'Dougharty, Helen Elizabeth (Nellie)(1886-1968).' Australian Dictionary of Biography Online. Canberra: National Centre of Biography, The Australian National University. http://adb.anu.edu.au/biography/ dougharty-helen-elizabeth-nellie-12891/text23289.

Schwartz, Carol. Interviewed by Nikki Henningham for the Women and Leadership in a Century of Australian Democracy Oral History Project, in Melbourne, 11 May, 22 June and 13 September 2011. National Library of Australia, Canberra. http://nla.gov.au/nla.oh-vn5216518.

Smith, S. Greig. 'Three Ladies from England.' Forum 7(2) (1954): 1-2.

Spence, Catherine. State Children in Australia. Adelaide: Vardon \& Sons, 1907.

Steinberg, Margaret and Lara Cain. Putting Paid to Prescribed Roles: A New Era for Australian Women and Philanthropy. Working Paper No. CPNS16, Centre of Philanthropy and Nonprofit Studies, Queensland University of Technology, Brisbane, 2003.

Stewart, Jean. 'Zina Beatrice Selwyn Cumbrae-Stewart: A Powerful Woman.' Journal of the Royal Historical Society of Queensland 19 (February 2005): 610-27.

Stewart, Noël. 'Clutterbuck, Katherine Mary (1861-1946).' Australian Dictionary of Biography Online. Canberra: National Centre of Biography, The Australian National University. http://adb.anu.edu.au/biography/clutterbuckkatherine-mary-5691/text9619.

Swain, Shurlee. 'Perhaps to Spite Her Children: The Philanthropy of Elizabeth Austin.' Australian Philanthropy 30 (1996): 10-15. 
Swain, Shurlee. 'Women and Philanthropy in Colonial and Post-Colonial Australia.' Voluntas 7(4) (1996): 428-43.

'The Death of Miss Sutherland, the Great Philanthropist.' Fitzroy City Press [Melbourne], 15 October 1909: 3. http://nla.gov.au/nla.news-article65684211.

'The Submerged Tenth.' The Mail [Adelaide], 17 February 1923: 18. http://nla. gov.au/nla.news-article63779161.

Transcript. Enough Rope, ABC TV, 23 June 2008. http://www.abc.net.au/tv/ enoughrope/transcripts/s2283021.htm.

'Women and Universities.' The Register [Adelaide], 8 June 1925: 5. http://nla. gov.au/nla.news-article54915469.

'Women Donors Investing in Women and Girls.' http://www.womendonors.org. au/index.php?option $=$ com_content $\&$ view $=$ article $\& i d=38 \&$ Itemid $=95$.

'Women of Power and Influence.' Compass, ABC TV, 25 February 2007. http:// www.abc.net.au/compass/s1835941.htm.

Woollacott, Angela. 'From Moral to Professional Authority: Secularism, Social Work and Middle-Class Women's Self Construction in WW1 Britain.' Journal of Women's History 10(2) (1998): 85-111. 
This text taken from Diversity in Leadership: Australian women, past and present, edited by Joy Damousi, Kim Rubenstein and Mary Tomsic, published 2014 by ANU Press, The Australian National University, Canberra, Australia. 